\title{
Entrepreneurship Intervention: Towards Transforming Education in Institutions of Higher Learning: A Case of One Public University in Zimbabwe
}

\author{
Gwendoline Vusumuzi Nani \\ Graduate School of Business, National University of Science and Technology, P.O. Box AC 939 - Ascot - \\ Bulawayo, Cnr. Gwanda Road/Cecil Avenue, Zimbabwe
}

\begin{abstract}
The study assessed selected university stakeholders' views and perceptions regarding the curriculum being offered at one public university in Zimbabwe and its alignment towards socio-economic needs. The study also sought ways of how entrepreneurship could be effectively infused into the university curriculum to address the challenge of unemployment. A qualitative case study involving thirty purposively selected participants was adopted. Participants included university administrators, lecturers, students, curriculum developers, captains of industry and the university community. Open ended questionnaires and in-depth face to face interviews were used to elicit responses which were later analysed to discern themes. Findings revealed that the curriculum offered partially addressed the needs of the market due to its failure to focus on entrepreneurial skills training. This tended to constrain students' self-reliance. Furthermore, entrepreneurship per se was not taught in some of the Faculties. The study concluded that the lack of a practical component was the missing link in fully addressing socio-economic needs and that Entrepreneurship was not a university wide module. The study recommended that for Entrepreneurship to address the socio-economic challenges, there was need to make it a university wide course that incorporates the practical component while consulting various stakeholders for input and relevance.
\end{abstract}

Keywords: skills training, Entrepreneurship, transformation, curriculum, market demands

DOI: $10.7176 / \mathrm{JEP} / 10-35-03$

Publication date: December $31^{\text {st }} 2019$

\section{Introduction}

Zimbabwe, like other developing countries is faced with a high rate of unemployment (Musonza, 2015; Mauchi, Karambakuwa, Gopo, Kosmas, Mangwende \& Gombarume, 2011; Ncube, 2008). Yearly, universities produce graduates who cannot find employment in the formal job market (Ndlovu, 2013). The question that comes to the fore is, 'What is now wrong with the educational system of Zimbabwe yet it used to be the envy of many?' Pillai (n.d:74) asserted that the educational system should address the needs of its economies, citizens and should equip individuals with the skills and attitudes necessary for them to adapt to changing conditions, and for constructive participation in the task of social change.

Chaube and Chaube (2005) quoted by Munikwa (2011) agree that the curriculum should be in sync with the needs of society for the knowledge offered to be worthwhile. Education should be closely related to the realities of life in all conceivable aspects in order to prepare the learner to fit into the environment in which one lives. Kurasha and Chabaya (2013) and (UNESCO-IBE 2006/7) allude to the afore-cited view that the general objective of the education system is to transform and develop the curriculum to make it more relevant to the country's cultural, socio-economic and skilled manpower requirements. Furthermore, the curriculum development is a key educational process that can boost the innovative capacity of a higher educational system. Munyanyiwa and Mutsau (2015) concur that curriculum plays a vital part in shaping student development. It is important to recognise the underlying factors and policy development both at global and national level which necessitate the paradigm shift towards entrepreneurial education due to globalisation, reduced economic activity and the high unemployment rate which have necessitated the need to create job creators instead of job seekers.

Kurasha and Alexander (2013) further explain that curriculum development should be a participatory approach that involves key stakeholders. In Zimbabwe, curriculum development is influenced by technological advancements, demands by the students, society expectations, industry and commerce, globalisation, partnerships by institutions, the need for professionalism in business, academic research to revamp the economy, competition among institutions and government expectations. According to Pedzisai, Tsvere and Nkhonde (2014), the education system which is a vehicle of social transformation is undergoing change to suit the prevailing societal interests, development, needs and aspirations by enhancing learners' achievement.

Implications that can be derived from the preceding section is that for education to be valuable, it has to serve the interests of its citizens and transform their lives for the better. For Entrepreneurship to address the needs of the Zimbabwean economy, there is need to identify the needs and challenges that Zimbabweans face, the resources and skills that Zimbabweans possess and then re-visit the educational curriculum, including the courses taught, in line with the needs of Zimbabweans. Therefore, the educational system should inculcate in our learners, the mind 
sets of being job creators and not job seekers as prescribed by the curriculum before the 1999 Nziramasanga Commission. This will enable youth, in particular, to positively contribute towards the economic growth and development of Zimbabwe. Yahaya (2011) cited by Anene and Imam (2011) asserts that the general objectives of entrepreneurship education are to: address the unemployment problem; to encourage universities to train human capital that will contribute towards national development; tenable universities to be enterprising for income generation and to instil an innovative and entrepreneurial culture among graduates. In this regard, the government of Zimbabwe sees entrepreneurship as a possible solution to the scourge of high unemployment.

\section{Background}

Long after its independence, the government of Zimbabwe set up the Nziramasanga Commission (1999) to assess the educational curriculum because of the cry that the educational system in Zimbabwe was too academic oriented, thereby offering less relevance to the world of work (Chiedza, Makaye \& Mandiudza, 2013). The Commission recommended the integration of core (theory and academic) and practical subjects; that is, a Two Path-Way education system. The idea was that students with an academic bias should take compulsory theory subjects and at least one and a maximum of two practical subjects. Integrating theory and practice would produce students who would enable the graduates to fit in both worlds and also appreciate the value of practical subjects. On that score, the Ministry of Primary and Secondary Education (MOSPE) has been able to inculcate entrepreneurial skills in primary and secondary students.

Although the Zimbabwe Ministry of Higher Education, Science and Technology Development has introduced Entrepreneurship, the challenge in some cases is the delivery approach which is classroom and teacher-centred (Nani, 2014; Mauchi et al. 2011). Katz (2007) cited by Maiyo, Rono, Ng'elechei \& Tubey (2016) opines that, for a society to have entrepreneurial spirit, it must begin with knowledge acquisition and then move to the practical aspects where an individual learns the skills. A more holistic approach should be used in teaching entrepreneurial courses to give students (with or without prior entrepreneurial experience) an opportunity to developing their skills, attributes and behaviour of a successful entrepreneur rather than focus solely on teaching students about entrepreneurship. Ayuo and Rono (2012) cited by Maiyo et al. (2016) assert that entrepreneurship education in universities and other tertiary institutions are providing knowledge "about" entrepreneurship and not 'skills' for entrepreneurship. This is because lecturers are stuck in the old school pedagogy of teaching and learning. The implication is that the Zimbabwean Higher Education system could be failing to meet the needs of the current environment.

Kurasha and Chabaya (2013) postulate that the quality of the national curriculum is based on the extent to which it meets individual attributes, the requirements of the national economy, the needs of society and the future challenges and aspirations of the nation. The Nziramasanga Commission was biased towards primary and secondary education. This study focuses on tertiary education. The question that this study sought to address is; Does the curriculum in the selected university reflect and address the needs of the Zimbabwean situation which is characterised by high unemployment, shrinking formal job market; liquidity challenges; more imports than exports and fuel challenges (Musonza, 2015; Ndlovu, 2013) among other challenges. Esene (2015) posits that one of the goals of tertiary education is to contribute to national development through relevant training and inculcation of skills that will enable graduates to be self-reliant.

The educational curriculum in Zimbabwe since the colonial era, right from high school level, was said to be too theoretical and academic. Although the government of Zimbabwe has introduced Entrepreneurship in the university curriculum, the unemployment rate continues to escalate. This prompted the researcher to find out from the university stakeholders of one public university, whether the curriculum offered factored in socio-economic needs; prospects of students' employment opportunities after completion of their studies and ways of effectively infusing Entrepreneurship into the university curriculum to address the challenge of unemployment. The study was guided by the following objectives:

- To establish from the selected stakeholders whether the curriculum offered in the university under study addressed Zimbabwe's market needs.

- $\quad$ To find out the changes that selected stakeholders would incorporate into the curriculum in the selected university to make it more relevant to Zimbabwe's market needs.

- To establish from the selected stakeholders ways in which Entrepreneurship can be effectively infused into the university curriculum.

It was hoped that the findings of this study would benefit various stakeholders of the selected public university such as university administrators and lecturers, university students, captains of industry and the community in developing ways of effectively infusing Entrepreneurship into the curriculum to enable graduates to create their own employment. Findings would also assist policy makers in making decisions that would enable the development of a curriculum that responds to the country's economic demands while serving as a reference point for future curriculum reforms. 


\section{Literature Review}

The study was premised in the experiential learning theories namely, Kolb (1984) and Dewey (1997). Kolb (1984) believed in active experimentation that is, planning and trying out what you have learnt and learning better with hands-on experiences. Dewey (1997), another proponent of experiential learning posited that learning is fast achieved not through mechanical drilling in prefabricated material, but by doing work and experimenting with things. Dewey (1997) aimed at integrating the school with society and the processes of learning with the actual problems of life. He believed that the school itself is a social institution through which social reform can and should take place. He believed that the purpose of education is to enable one to realise his or her full potential and the ability to use acquired skills for the greater good of society. Education and schooling are instrumental in creating social change and reform. The same theory can be applicable to the teaching of Entrepreneurship in higher education where students should learn by doing and linking with the needs of society.

According to Waita (2014), increasing attention is being paid to entrepreneurial activities and education which are considered crucial to economic development, growth, innovation and job creation. Focusing on the youth while they are still at school provides a lasting solution to employment generation. Anene and Imam (2011) are in agreement that even in Nigeria, like in other developing countries, the aim of the education system is to produce skilled graduates who will contribute to the nation's development. Graduates from universities and polytechnics fail to get employment in the formal sector and that leads to their general frustration, idleness, redundancy and social insecurity hence the importance of a university curriculum that addresses society's expectations and their needs.

Olofin (2013:38) cited by Adebayo (2013) is of the view that universities should regularly review entrepreneurial courses and not only focus on the theoretical aspect of Entrepreneurship but should reach out to their alumni body with a view to attracting successful entrepreneurs to mentor students through the practical aspects of becoming successful and self-reliant entrepreneurs. Efe (2014) concurs by saying that education is very important in impartation of appropriate skills, capacities, values, knowledge and attitudes which can be used in the transformation of individuals, communities and nations at large. Entrepreneurship education can be used for wealth creation, poverty reduction, socio-economic empowerment and sustained self and national development.

\section{Research Methodology}

A qualitative approach was utilised for this study. The research design was a case study of one public university in Zimbabwe. A case study design involves the detailed and intensive analysis of one or more cases which the researcher aims to study in depth. Exponents of the case study design often favour qualitative methods such as semi-structured interviewing to generate an intensive detailed examination of a case (Bryman, Bell, Hirshsohn, Dos Santos, Du Toit, Masenge, Van Aardt \& Wagner, 2017; Bryman, 2012; Cooper \& Schindler, 2008).

The researcher engaged with thirty purposively selected stakeholders, comprising five university administrators, five lecturers, five students, five curriculum developers, five captains of industry and five community members. The sample was deemed adequate as the thrust was in obtaining information rich data on the subject under study. This is a characteristic of qualitative studies, as opposed to the statistical representativeness of quantitative studies. Participants were given codes for the sake of anonymity where university administrators were coded (UA, 1-5); university lecturers (UL, 1-5); university students (US, 1-5); curriculum developers (CD, $1-5)$; captains of industry (COI, 1-5) and community members (CM, 1-5).

Data collection instruments comprised open ended questionnaires, face-to-face and telephonic interviews where there was need for probing. To test for credibility and authenticity of the data, member checking was done prior to analysis. Data analysis was based on research objectives where various themes emerged from each category of participants. According to Bell et al. (2017), the goal of thematic analysis is to identify, analyse and describe patterns, or themes, across the data set and extends to interpreting features of the research topic. Ethical concerns were addressed prior to the commencement of the study and these involved requesting for permission to conduct the study in the selected university and consent from the participants. Issues pertaining to anonymity, protection from harm and confidentiality were observed.

\section{Results}

The objectives of the study were three pronged: firstly to find out selected university stakeholders' views and perceptions on whether the curriculum being offered at one public university in Zimbabwe was aligned with Zimbabwe's socio-economic needs. Secondly, to find out the changes that selected stakeholders would make to the curriculum in the selected university to make it more relevant to Zimbabwe's socio-economic needs. Thirdly, how entrepreneurship could be effectively infused in the university curriculum so as to address Zimbabwe's socioeconomic needs. Data was analysed according to research objectives and discussion of results was based on the themes that emerged from each category of participants.

8.1 Research Objective 1. To establish from the selected stakeholders whether the curriculum offered in the university under study addressed Zimbabwe's socio-economic needs. 
The first objective related to whether the curriculum offered by the university under study addressed Zimbabwe's socio-economic needs. Based on the responses given, most of the participants felt that the curriculum offered partially met Zimbabwe's socio-economic needs. What follows are the participants' responses.

UA1: I feel the present curriculum does so partially. The focus should be on self-employment.

UA2: To a certain extent yes, the curriculum offered resonates with the aspects of sustainable development.

AU3: It doesn't. It can only be said to be addressing issues of sustainability when our graduates can manage to employ themselves.

UA4: Although some of the courses offered are what the industry needs, what has to be taken into account is, not all graduates will find jobs in the formal market. These courses will create employees and very few employers which is what our economy wants.

UA5: We cannot say the curriculum fully addresses the needs of our economy when the rate of unemployment is still so high.

When requested to give justification for the answers they gave pertaining to their perceptions of the university curriculum, the following answers were given.

UA1: The University lacks in so many ways in terms of technology, innovation and creativity. Some degrees have outlived their time given the current challenges being faced by Zimbabwe.

UA2: The curriculum offered is a hybrid type. The curriculum is engineering. This means that products of such a curriculum can be produced. From an engineering perspective, industry can be assisted.

UA3: From undergraduate to master's levels, degree programmes are not inclined to train graduates to be entrepreneurs but employees of organisations. At postgraduate level, the recruitment exercise focuses on people with managerial and not entrepreneurial experience.

UA4: When the curriculum was crafted, it addressed industry but because of the harsh economic environment and the increase in the number of companies closing down, our curriculum is being subjected to so much scrutiny.

UA5: You can only judge the soundness of a curriculum through the uptake of the graduates. Most of our graduates are failing to get employment. Many of our graduates have resorted to employing themselves.

Reasons given by the participants were that the curriculum did not fully address market needs because the unemployment rate is still very high. Some degrees have been rendered irrelevant due to technological advancement. There is lack of creativity and innovation and the environment was not conducive for full exploitation of these traits. These findings contradict views by Chaube and Chaube (2005) quoted by Munikwa (2011) and Kurasha and Chabaya (2013) that the curriculum should be in sync with the needs of society for the knowledge offered to be worthwhile. The results in this study are a pointer to the contrary.

The views expressed by another group of selected participants showed some disagreements with the afore-cited. Most of the participants in the next category indicated that after completion, their graduates were on demand within and beyond the borders and therefore, the curriculum addressed Zimbabwe's socio-economic needs. Their responses attest to this.

UL1: Highly in demand both in Zimbabwe and in the region.

UL2: Almost 75 percent of our graduates get employment.

UL3: They are employable. Most of them are in demand even beyond the borders.

UL5: Relatively highly employable in all sectors of the economy, given that management is relevant in all businesses and industries.

Although the participants highlighted that their graduates were employable, the truth is that not all of them can be absorbed in the formal market. The Zimbabwean market demands graduates who can employ themselves and sustain their livelihoods and not wholly depend on employment as opportunities continue to shrink. Education should first serve the needs of its own people before focusing on beyond the borders. Through the educational investment in its people, the government is hoping that the needs of its country would be met first. The implication from the participants is that the degree programmes offered by the university under study are relevant and marketable though some participant administrators had their own reservations. The trend should be towards graduates employing themselves because the current situation is a pointer to the fact that in the near future, job opportunities will simply be non-existent as shown by the following participants' sentiments.

UL2: Those that are faced with challenges, it is because of the abnormal economic situation. The economic environment is not conducive for businesses to operate. Companies are closing down due to a plethora of reasons such as shortage of foreign currency to import raw materials, liquidity crisis and fuel shortages. The list is endless. UL5: The economy has dwindled significantly making jobs hard to come by, not only for students but for all prospective employees in the country. This change in the economy has resulted in the sprouting of SMEs and the informal sector, which require a lot of technical and managerial skills. Our students lack the entrepreneurial skills which are now a prerequisite for the current economy.

Most of the participants blamed lack of employment of their graduates on the non-performing economy except for one participant who felt that graduates lacked entrepreneurial skills. One would argue and say the non-performing economy is not an event. People saw it coming or are experiencing it. Therefore, attempts should have been made 
to develop a curriculum that would enable graduates to create their own employment even in the face of adversity. A possible solution would be as one participant put it, a need to equip students with entrepreneurial skills.

Another group of participants who were interviewed were university students (US). Most of the participants in the US category felt that the curriculum was more biased towards job seeking instead of creation of employment. However, there were some participants who felt that the degree programmes they were pursuing would equip them with the necessary skills to start their own businesses.

US2: I am gaining the necessary education and skills required to effectively run the businesses that I own which are across several sectors namely, consultancy, mining and farming. More so, they are in different geographical areas. All these differ in their approach and management, and I believe that the course that I am pursuing will give me the skills to consolidate my efforts and run my businesses efficiently and effectively.

US3: The modules are relevant to the demands of the industry and self-development.

US5: I am a technical person. I intend to set up a business after completing my studies. This is why I need to gain expert knowledge in running a business.

The responses given were indicative of the need to acquire skills to enable graduates to run their own businesses and companies effectively and sustainably. These views corroborate those of Efe (2014) who asserts that education is very important in impartation of appropriate skills, capacities, values, knowledge and attitudes which can be used in the transformation of individuals, communities and nations at large.

Pertaining to entrepreneurial opportunities in the degree programmes being pursued, participants had this to say: US1: The modules are rich and enable one to establish a business venture.

US2: The degree is opening up a lot of entrepreneurial opportunities as it assists in identifying various opportunities that one would ordinarily dismiss if they had not gone through the programme.

US5: Most of the technical people lack business acumen so I will create a competitive advantage once I acquire knowledge in entrepreneurship. I don't intend to look for employment but I will start my own business.

The major contributions that emerged from the participants were that of creating their own employment and for others and contributing to the tax base. These are shown in the responses that follow.

US1: By establishing a formal business, the economy will benefit through employment creation and taxes.

US2: There are two ways that I would like to contribute to the economy of the country:

(a) creating jobs through my entrepreneurial ventures and

(b) sit on the board of one of the state owned enterprises to advise them on ways to improve profitability and sustainability instead of always relying on the government.

US3: To uphold corporate governance issues in private and public sectors in order to prevent decline of industries caused by lack of recognition of corporate governance issues.

US4: To encourage relatives and friends to start their own businesses in order to employ other people and also contribute to gross domestic product.

US5: Creating employment for myself and others and thus contributing to the tax base.

Responses from the corporate world were a mixed bag with some expressing the views that the interns had very little or nothing to show in terms of entrepreneurial skills which is what the market demands. Others felt that even if interns had the skills, companies do not allow them to introduce their ideas as they have targets to achieve.

COI1: I feel that students who come for attachment do not showcase their entrepreneurial skills effectively. Usually they finish their attachment without having an opportunity to introduce new ideas in the areas they will be attached. I strongly believe that our organisation does not give them room and encouragement to demonstrate their entrepreneurial capabilities.

COI2: I think this is very industry specific. In the tourism sector, students don't have a room to showcase any entrepreneurial skills due to the fact that the industry is well marketed and often the contracts are sealed. Any entrepreneurial skills would need foreign travel for marketing, and without any prior tourism experience this simply isn't possible. I think their skills are more relevant in areas such as retail/manufacturing which are less "regulated" and students can actually proffer ideas that can be implemented.

COI3: In my organisation, one of the biggest retail firms in Zimbabwe, entrepreneurship is regarded as the small business activities that people do to support their earned income. Entrepreneurs are viewed as the people who run their own small firms, and is not regarded as a concept that is applicable in the corporate world. Employees and management here talk of entrepreneurship in the informal world and use it to describe the workers' side businesses, like selling perfumes, chickens, fruit and vegetables which they do privately. It is never discussed in strategy or planning. The students who join our organisation could be failing to exhibit any entrepreneurial skills or characteristics. Students in general do not unravel the existing positions of things they just fit in. College leavers are generally scared to stand out, to question the status quo and to suggest new innovative ideas and ways of doing things. They follow the leaders and follow existing patterns.

COI4: There is very little in terms of entrepreneurial skills that students bring. Most of the students tend to run with the wave and not add much in terms of new ideas.

COI5: Students are not given room to showcase their skills. 
The statements that follow are responses from the community participants who were asked to give their perceptions on whether the graduates from the university under study possessed the skills to serve Zimbabwe's socio-economic needs.

CM1: First and foremost I would like to say, while efforts are being made by particular lecturers to mould the graduates for the challenges ahead, a lot still needs to be done towards appropriately grooming them to fit in the current environment. This is because:

There is too much theory and indoctrination that graduates go through. That as a result does not give them an edge. This may be due to a number of reasons like: the curriculum has not changed much since it was adopted from the colonial master. It should be tailor made to suit our economic context. It is driven by numbers more than quality. There are poor facilities in the universities as well as bench method of education where learners sit and consume from the lecturers and books than doing targeted projects that are manipulated and exploited to churn out a profit in this economic environment. Learning is not paced with the real economic world. Another reason could be that there are no incentives to encourage inventions. Learners are not pushed to compete to produce something that will be used in industry. Generally, the quality of graduates leaves a lot to be desired.

CM2: There are a few graduates who get employed because they choose wrong degree programmes. Engineering and manufacturing degree courses are essential so that after completion, these graduates can create employment and grow the economy.

CM3: Our graduates are highly reputable, locally, regionally and internationally. This is evidenced by the high positions they occupy in industry and their general proficiency.

CM4: The quality of our graduates, may, however, be improved particularly for STEM. Inadequacy of laboratories and workshops leave our graduates vulnerable to facilities in industry.

CM5: The quality of the graduates we have is not well equipped to becoming the generators of employment. They are trained to become employees.

What comes out vividly in most of these responses is inadequate resources and poor methods of lesson delivery. The general feeling is that graduates from the university under study are not fully equipped for the prevailing environment, hence more needs to be done.

8.2 Research Objective 2. To find out the changes that selected stakeholders would make to the curriculum in the selected university to make it more relevant to Zimbabwe's socio-economic needs.

Participants were asked to respond to a question on the changes that they would make if they were to re-design the curriculum. The majority as shown in their responses indicated that they would introduce Entrepreneurship to enable students to create their own employment. One participant went further to say Entrepreneurship should have a practical component where students would be made to run their own businesses or other people's businesses during their training.

UL2: I would introduce Entrepreneurship as a stand-alone degree like what other universities have done. It is important to benchmark with other universities.

UL3: Inclusion of courses such as Entrepreneurship so that students are able to sustain themselves even if they are not formally employed.

UL4: Inclusion of the practical component in the teaching of Entrepreneurship.

UL5: The practical aspect needs to be incorporated. If possible, a technical skill and not Advanced Level should be a prerequisite for enrolment. Practical entrepreneurship skills should be incorporated into the curricula. Students should be running some businesses as part of their 4-year training for a degree (These could be their own businesses or other people's businesses).

These views are in tandem with Kolb (1984) and Dewey's (1997) theories that learning is more effective when students are practically involved. The overarching changes to the current curriculum hinge on the need to introduce Entrepreneurship in the whole university, incorporate practical sessions in lectures and create room for visits by captains of industry as shown in the answers that follow.

US1: An additional module to deal with Project Management and Information Systems is key in this programme. US3: I would ensure that Entrepreneurship is taught in all faculties and highly emphasised.

US5: All modules to involve external guests for presentations. This bridges the gap between theory and practice. The findings of this study resonate with those of Kurasha and Chabaya (2013) that curriculum development should be participatory and should involve key stakeholders.

The curriculum development participants were asked to explain how they would re-design the curriculum and make it more effective with entrepreneurship. All of them indicated that Entrepreneurship would be a compulsory course for the whole university as the current situation needs graduates with entrepreneurial knowledge and skills; graduates who understand the needs of the economy and can address those needs.

CD1: Incorporate Entrepreneurship so that graduates are equipped with skills that will assist them to earn a living. The current Zimbabwean situation needs graduates who will generate employment for themselves and others. CD2: Incorporate Entrepreneurship at every stage or level not just in the final year; catch them young. Allow students to do practical subjects and award those students that excel. 
CD3: A Faculty Course in Entrepreneurship would be more appropriate for all students.

CD4: Make Entrepreneurship a compulsory course.

CD5: Make students at undergraduate level come up with implementable entrepreneurial projects.

Participants from the community group made the following contributions to propose changes in the curriculum.

CM1: Much needs to be designed in the curriculum because therein lies the cause of the weaknesses in our students. Students must be trained to be self-sufficient. Without this, graduates will be useful only as employees. The largest business success stories are in SMEs and these are largely un-educated people. Government and financial institutions should also come up with programmes to financially assist in this area.

As part of business training, students should be taught, customer care and responsibility so that as they mature they appreciate the value of these in business.

Research and innovation should be incorporated in the curriculum, and this should be project based not merely theorised. Some workshop practice for those in engineering should be encouraged. We should be competing with international universities in the area of research and discoveries. As it is, we probably have nothing to boast about in that area.

In closing, there has to be a shift in our approach as institutions; to be in line with the economic changes in the country and the world. Our education should follow that trend as well.

CM3: Communication can revolutionise ideas, breathe new life into a product or brand. Communication is the basic pivot to success or failure of a business.

CM4: Strategy formulation is an indispensable skill in putting up plans of action for businesses.

CM5: Knowing how to manage and grow finances is key to success in business. Lack of the ability to manage finances exposes entrepreneurs to risk of becoming unsustainable which often leads to bankruptcy.

The aforesaid responses show concern by members of the community about lack of emphasis on equipping students with skills relevant for the market. The issue of lack of practical component has been registered as an area that is not adequately addressed in the university under study. Members of the community are saying that if the university is ill equipped it should rent premises so that students acquire skills that will make them self-reliant.

8.3 Research Objective 3. To establish from the selected stakeholders ways in which Entrepreneurship can be effectively infused into the university curriculum.

On being asked how they would re-design the curriculum to make it more effective with Entrepreneurship, this is what the participants had to say.

UA1: I would make the courses more relevant to the current economic situation so that graduates can create their own employment after completion.

UA2: Improve and increase the Entrepreneurship content in the design of the curriculum.

UA3: Entrepreneurship is supposed to form part of the core courses. Currently it is only one module but it should be incorporated in all modules and not just one. At enrolment level, more entrepreneurially inclined students should be taken on board.

There is also need to include the practical component in the Entrepreneurship module as it is a 'hands on' subject. Theory only is inadequate. It does not produce a whole being.

For internship, there is need to attach students where they can be relevantly mentored in Entrepreneurship.

AU4: Introduce Entrepreneurship to the whole university.

AU5: I would improve the university infrastructure which would allow students to do Entrepreneurship practically. A second category of participants' responses to a question on how Entrepreneurship could be infused in the subjects that they teach, evoked the following responses:

UL1: We can employ a more practical aspect to use of statistics and mathematics in business although most of what I teach is already employing the practical side of the business.

UL2: Digital Marketing graduates can start their own social media agencies. Students that will have done Entrepreneurship might have fewer challenges in setting up their own businesses. Once you have studied Entrepreneurship and gone through all the basics required for one to start a business, one does not have to wait to be employed. Even with Sales Management and Professional Selling, one can start his or her own business.

UL3: By adding some Entrepreneurship concepts in suitable sections of the modules taught.

UL5: Students should have their own business ideas incubated and then be assisted or mentored to grow them. Entrepreneurship courses should be more practical, not theoretical. Finances with favourable terms and other resources should be availed to students.

Participants' responses all point to the fact that the curriculum as a whole must include Entrepreneurship to equip students with skills to start their own businesses. Presently, the university under study is offering Entrepreneurship as a module but without a practical component. Besides, the module is not offered in the whole university. Some of the faculties have not included it in their curriculum.

The participants were however calling for the government to assist them by availing information on running of businesses, arranging regional and international visits, guidance on the setting up and running of businesses and provision of local and international business links as reflected in the responses that follow. 
US1: Assist with information related to our entrepreneurial endeavours.

US2: The university should ensure that during the course of the programme, we do not only visit local entrepreneurs, but also visit other countries regionally and internationally.

US3: The university can help by assisting with the protection of patents and copyrights.

US4: Guide us on how to structure a new business.

US5: Guide us on how to run consultancy services. Provide links to various experts in the field of entrepreneurship both local and abroad. Enabling access to published research articles in line with new business formation and consultancy services.

The views and perceptions that follow were those expressed by the participants from industry on how entrepreneurship could be infused into the university curriculum.

COI1: In order to close the gap between theory and practice, it would be good for students to have captains of industry being invited to lectures and allow students to ask questions about the practical applications of theories in real life settings.

COI2: Students studying towards Entrepreneurship should not be allowed to graduate unless they can team up and start ideas that generate some form of income. To merely pass a student on the basis of theory defeats the whole purpose of the curriculum. I believe there is a need to be more radical in the manner in which the learning is imparted.

COI3: Every degree programme should have the Entrepreneurship module as a compulsory course. All undergraduate students must start up and run a project (minimum 3 years) during their stay at university, then take it or leave it at the university when they graduate.

The university can host and offer the highest new venture competition prizes as a Glitz and Glamour Awards Ceremony. Recognition of these winners at graduation ceremonies can be good incentives.

The university could host an annual "Entrepreneurship Summit" where all stakeholders participate including government, institutions, corporate leaders, ambassadors and successful entrepreneurs are brought together for a common agenda.

Establish a think tank that is focused on building entrepreneurs of all kinds where applied experiences, mentoring, and milestone achievements are designed to move early-stage ventures from prototype to successful launch and growth.

The university could lobby the Ministry of Higher Education to ensure that all students interested in enrolling at their institutions should have gone through a course on Foundations of Entrepreneurship (FOE).

The university could set up the FOE yearlong immersion programme targeting corporates and organisations where they go into the business world and train business leaders and boards.

CO14: Entrepreneurial skills need to be taught as part of the curriculum.

COI5: Every degree programme should have the Entrepreneurship module as a compulsory course.

\section{Discussion}

Findings revealed that for Entrepreneurship to be effectively infused in the curriculum at the university under study, the introduction of the practical component of the subject is crucial. These views tally with findings by Nani (2014) and Katz (2007) cited by Maiyo et al. (2016) that for a society to have an entrepreneurial spirit, it must include the acquisition of both knowledge and skills.

The Entrepreneurship module has always been taught as a service course in the studied university. It has always been offered to some departments while other faculties have not yet embraced it. The mode of delivery has largely been theoretical and assessment has always been in the form of theoretical examinations. It is only when students go for industrial attachment in the third year that they get exposure. While attachment bridges the gap between theory and practice, the shortcoming is that some students do not get attached in areas where their entrepreneurial skills will be sharpened. They may also fail to get internship in organisations that give room for creativity and innovation opportunities. Participants' views were that as long as the focus was on theory not much could be achieved in terms of addressing the socio-economic needs of Zimbabwe. These findings are in tandem with Chaube and Chaube, quoted by Munikwa (2011); Kurasha and Chabaya (2013), Munyanyiwa and Mutsau (2015) that the curriculum should be structured such that it addresses the needs of the people it is intended for. It also emerged from the results that there was a need to consult key stakeholders as asserted by Kurasha and Chabaya (2013) that the development of the curriculum should follow a participatory approach that involves key stakeholders.

Although the subjects offered at the university under study are those demanded by the economy, not all graduates are employable hence the need to focus on Entrepreneurship which can enable those who cannot be gainfully employed to employ themselves and others.

\section{Conclusion}

The study focused on assessing selected university stakeholders' views and perceptions regarding the curriculum 
being offered at one public university in Zimbabwe and its alignment towards socio-economic needs. Ways of how Entrepreneurship could be effectively infused into the university curriculum to address the challenge of unemployment were also looked into. Results showed that the curriculum offered partially addressed the needs of the market as it lacked entrepreneurial skills training. Entrepreneurship per se was also not taught in some of the faculties. Based on the findings, the study concluded that the practical approach to teaching Entrepreneurship was the missing link for Entrepreneurship to be effectively taught so as to address the challenge of unemployment.

Recommendations from the study were that Entrepreneurship should be made compulsory to all the students in institutions of higher education, including non-commerce students and the practical component be incorporated in the curriculum.

There is need to re-conceptualise and revamp the educational system in higher education in Zimbabwe so that it responds to the country's economic demands and contribute to economic development. There is also need to ensure that the Zimbabwean education system is not only manifested in certificates but should translate into spinoffs beneficial to the people of Zimbabwe. The curriculum must resonate with the socio-economic challenges that occur daily and the inclusion of Entrepreneurship in the curriculum is a step in the right direction provided lesson delivery results in the acquisition of entrepreneurial skills. The content taught and the delivery methods used should address the challenges of unemployment and reduction of poverty.

The curriculum in the university under study needs to be inclined towards entrepreneurial activities especially creativity and innovation. The bias should be towards the practical components of the subjects where students are involved in creative and innovative aspects of learning. There is need to usher in young entrepreneurs with a technical mind-set. University technological hubs should be used as springboards for students' business ideas.

Collaboration with industry with regards to course content is crucial. Such an engagement will also allow the university to keep abreast with goings-on in industry and keep it relevant. There is need for captains of industry to be actively involved during curriculum design and in mentoring those aspiring to be entrepreneurs. Students need to engage and interact with people with hands-on experience who have endured the challenges in the business world. Since this study established that some faculties in the university did not offer the Entrepreneurship module, further studies could be conducted on the feasibility of offering a university wide Entrepreneurship course or a stand-alone Entrepreneurship degree.

\section{References}

Anene, J. \& Imam, I. (2011). Entrepreneurship Education Curriculum Content for Undergraduate Students in Nigerian Universities. Journal of Education and Practice, Vol 2 (3).

Bryman, A. Bell, E., Hirshsohn, P., Dos Santos, A., Du Toit, J., Masenge, A, Van Aardt, I \& Wagner, C. (2017). Research Methodology. Southern Africa. Oxford University Press.

Bryman A. (2012). Social research methods. (4 ${ }^{\text {th }}$ edition) Oxford, UK: Oxford University Press.

Chiedza, W., Makaye, J., \& Mandiudza, L. (2013). Vocationalisation of Secondary Schools: Implementation Reality or Fallacy? European Journal of Sustainable Development, 2 (1), 123-132.

Cooper D. R. \& Schindler P. (2008). Business research methods. Singapore: McGraw-Hill/Irwin.

Dewey, J. (1997). Experience and Education. New York: Macmillan.

Efe, A. J. (2014). Entrepreneurship Education: A Panacea for Unemployment, Poverty Reduction and National Insecurity in Developing and Underdeveloped Countries. American International Journal of Contemporary Research. Vol 4 (3), 2014.

Esene, R. A. (2015). Implementation of Entrepreneurship Development Education Curriculum of Polytechnic Education towards Unemployment Reduction among Graduates of Office Technology and Management in the Nigerian South-South Zone. European Journal of Research and Reflection in Management Sciences. Volume 3(1), 2015

Kolb, D. A. (1984). Experiential Learning: Experience As The Source Of Learning and Development (Volume 1). Prentice Hall, Englewood Cliffs, N. J.

Kurasha, P. \& Chabaya, C. R. (2013). Curriculum Development and Implementation: Factors contributing towards curriculum development in Zimbabwe Higher Education system. European Social Sciences Research Journal. Vol. 1(1), 55-65.

Maiyo, J. K., Rono, A. J., Ng'elechei, R. J. \& Tubey, R. (2016). An Analysis of the Trends and Issues in Entrepreneurship Education. Africa Journal of Technical and Vocational Education and Training. 2016, 1(1), 179-187.

Mauchi, F. N., Karambakuwa, R. T., Gopo, R. N., Kosmas, Mangwende, S., \& Gombarume, F. B. (2011). Entrepreneurship education lessons: A Case of Zimbabwean Tertiary Education Institutions. Educational Research, 2 (7), 1306-1311.

Munikwa, S. (2011). Analysis of the Current Zimbabwe's Secondary School Two Path-Way Education Curriculum. Journal of Innovative Research in Education. 1(1), 21-35.

Munyanyiwa, T. \& Mutsau, M. (2015). An analysis of Entrepreneurial Curriculum Content: A case study of the 
University Of Zimbabwe Faculty Of Commerce. European Journal of Business and Management. Vol 7 (20), 198-204.

Musonza, B. (2015). De-industrialisation: Zimbabwe's economic crisis demystified. Retrieved from: https://www.the independent.co.zw/2015/07/03/de-industrialisation-zims-economic-crisis-demystified.

Nani, G. V. (2014). Teaching of Entrepreneurship as a subject in Zimbabwean schools-What are the appropriate teaching methods? A case of Bulawayo Metropolitan Schools. Zimbabwe Journal of Science and Technology. 1-7.

Ncube, M. (2008). The Labour Market and Decent Work Agenda in Southern Africa: Evidence and Challenges. International Labour Organisation (ILO) Sub-Regional Office for Southern Africa, Harare, Zimbabwe. Issue Paper No. 31.

Ndlovu, E. (2013). Graduates must be job creators. Retrieved from: http//www.chronicle.co.zw/graduates-mustbe-job-creators.

Nziramasanga, C. T.(1999). Report of the Presidential Commission of Inquiry into Education and Training. Zimbabwe Government. Retrieved from: http//hdl.handle.net/10646/1191.

Pedzisai, C. Tswere, M. \& Nkhonde, M. (2014). The Zimbabwe 2 Pathway Education Curriculum: Insights into Policy Implementation, Challenges and Opportunities. International Journal of Advanced Research in Management and Social Sciences. Vol 3(5), 162-173.

Pillai, V. N. Rajashekharan. (n.d). Ghandi's Concept on Education and its Relevance in the Present Day. Retrieved from www.iop.or.ip/0414/pillai.

UNESCO-IBE. (2009/7).World data on Education $6^{\text {th }}$ Edition 2006/7. Revised Version August 2006. Retrieved from http://www.ibe.unesco.org.

Waita, D. M. (2014). Influence of Entrepreneurship Education on Economic growth of County Government in Kenya: A case of Nairobi County. International Academic Journal of Information Sciences and Project Management. Volume 1(2), 59-79. 